\title{
Motions in the Body, Sensations in the Mind
}

Malebranche's Mechanics of Sensory Perception and Taste

\section{Katharine J. Hamerton}

\section{(2) OpenEdition Journals}

Electronic version

URL: http://journals.openedition.org/aes/1889

DOI: 10.4000/aes.1889

ISSN: 2258-093X

\section{Publisher}

Laboratoire LISAA

\section{Electronic reference}

Katharine J. Hamerton, "Motions in the Body, Sensations in the Mind ", Arts et Savoirs [Online],

11 | 2019, Online since 15 July 2019, connection on 05 September 2019. URL : http://

journals.openedition.org/aes/1889; DOI : 10.4000/aes.1889

This text was automatically generated on 5 September 2019.

Centre de recherche LISAA (Littératures SAvoirs et Arts) 


\title{
Motions in the Body, Sensations in the Mind
}

\author{
Malebranche's Mechanics of Sensory Perception and Taste
}

Katharine J. Hamerton

\section{Questioning the Favored Quality of Taste}

1 Aristocratic French society in the second half of the seventeenth century pithily held that taste was an "instinct of reason" or a sentiment "in harmony with reason". To know something through taste was to know it through intuition more than through reasoning: as the very worldly chevalier de Méré explained, "good taste is always based on very solid reasons, but most often, without benefit of reasoning" ${ }^{1}$. Taste was remarkable because this intuitive kind of reason - put another way, this correct intuition - was a feeling that immediately, automatically emerged whenever the mind was presented with a matter for judgment about whether something was pleasing. And despite that effortless immediacy, with no need for reflection, taste arrived at the identical judgment that reason would have done. As La Rochefoucauld put it, "There are those who, by a sort of instinct, the cause of which they don't know, decide about what is presented to them, and always take the right side." ${ }^{2}$ More remarkably, taste was, some said, more accurate than reason. Thus, for the Jesuit Dominique Bouhours, pre-eminent honnête theorist of the last three decades of the 1600 s and author of two canonical books establishing mondain views on sociability and literature, "Good taste is the first movement, or so to speak, a kind of instinct of right reason which carries it [reason] along with rapidity and which conducts it more surely than all the reasonings which it could make." ${ }^{3}$ This instinctive accuracy and harmonic affiliation with reason fascinated taste's honnête proponents ${ }^{4}$. Effortless, intuitive, felt more than thought (never reasoned out), instantaneous: that was the mondain consensus about the favored new property of taste, which, wonderfully and mysteriously, always knew just the right answer about what was pleasing and appropriate ${ }^{5}$. Taste was the painless worldly guide to judging what pleased (and did not) in literature, objects, art, fashion, and, of course, other people's behaviors ${ }^{6}$. 
2 Today, we are skeptical of such beliefs, having come to see them, in part, as working in the cultural service of an aristocracy that sought distinction and recrafted its identity under the pressures of absolutism and increased elite social mobility; we also tend to regard taste notions of this and other periods as discursive tools used to construct and maintain class boundaries more generally ${ }^{7}$. Long before Pierre Bourdieu and others had turned their gaze on French worldly cultural politics, however, the Augustinian and Cartesian theologian and philosopher Nicolas Malebranche (1638-1715) had called these beliefs into question. He did so by considering taste mechanically, approaching it as a kind of sensory perception of material objects by material bodies in a Cartesian universe of mind and matter. His analysis of the senses and the physical world they perceive posed tremendous challenges to these honnête views by undermining the fundamental assumptions his aristocratic contemporaries held about the world and their perceptions of it. Not for him the elitist nonsense that graceful noble minds possess some effortless natural superiority, nor even the commonsensical notion that the world exists as we perceive it. Malebranche, instead, used science to show what taste, human beings, and the world actually were. In the process he demolished worldly claims about a mental property called taste, somehow mysteriously aligned with reason. Malebranche was the Bourdieu of the grand siècle.

3 A critically important thinker in the reign of Louis XIV, Malebranche is still known for his philosophical synthesis, in which he explained Augustinian views of Original Sin and postlapsarian pleasure-seeking human nature in the Cartesian terms of mind-matter interaction. Since the Fall, he held, the body (matter, res extensa) had gained the upper hand over the immaterial soul or mind (res cogitans), promoting error and sin. Humans had come to will bad actions because of their erroneous, bodily-inflected perceptions of the world and their own good. Every aspect of intellect and will touched by the body had been affected (sensation, imagination, and the passions), and those embodied mental elements then affected even the pure mind's intellectual and moral decisions. Thus, a host of epistemological and moral errors followed the Falls. Within this philosophy, Malebranche viewed sensory perception with extreme skepticism, holding that our sensations accurately report our bodies' needs, but not the true state of the world, to the $\operatorname{mind}^{9}$.

4 In this article, I focus on Malebranche's mechanical explanations for why people receive different sensations from the same object - in general but especially in terms of pain and pleasure - to establish that he thought of taste as a sensory perception. As such, it was as erroneous and relativistic, for him, as any other sensation. This mechanical, sensory science spelled death for the mondain vision of a correct standard of good taste automatically in line with reason. Indeed, Malebranche's broader epistemological program, as detailed in his chef d'œuvre, De la recherche de la vérité (1674-5, with revised editions until 1712), linked the attention people paid to taste and its mental cultivation with error and the inability to find truth. But Malebranche's worldly readers chose to interpret him differently ${ }^{10}$. While my main objective is to explore Malebranche's arguments in order to explain their negative ramifications for contemporary worldly views of taste, I will briefly discuss in my conclusion the broader significance of Malebranche and his worldly re-appropriation for the Enlightenment. 


\section{The Mechanics of Sensory Perception}

5

Mechanical explanations of exactly how the brain received the sensory messages caused by the physical impact of external objects on the human body varied during the years when Malebranche was writing the Recherche. By the 1670s, most, Malebranche included, followed the anatomical discoveries of Thomas Willis and agreed that the brain was the seat of the soul and dependent upon the nerves for all external information via the senses, which gave both brain and nerves new epistemological primacy ${ }^{11}$. Malebranche held that the soul "resides in" that part of the brain that receives sensory information from the nerves ${ }^{12}$. But how was information transmitted to the brain, and then to the mind? Malebranche's answer about how matter affects sensing human bodies extended the then dominant Cartesian mechanical model of object-object interaction, premised on force and motion being transmissible only through physical contact; human bodies, after all, were inert res extensa to Cartesians, and obeyed the laws of motion that governed all matter ${ }^{13}$. Minute invisible particles, Malebranche thought, left objects to strike bodily surfaces, and their transmitted force continued to the brain through a mechanical communication of motion and impact in the nerves. This took place in one of two ways. He leaned towards the hollow nerves theory, which held "that nerve filaments are hollow like little canals and are completely filled with animal spirits, especially when one is awake; that when the end of these filaments is disturbed, the spirits contained in them transmit to the brain the vibrations they have received from without"; but he thought it possible that the nervous fibers, physically struck from outside, might transmit vibrations through "the continuous displacement of the filaments right up to the brain"14. Whether through vibrating nervous fibers or circulating animal spirits, either or both adequately accounted for the mechanical communication of sensory messages to the brain $(S T, 49-51)^{15}$. At that point, Malebranche believed that brain motions, following regular natural laws, became the occasional causes of thoughts and feelings in minds.

Epistemologically, there are no obvious or necessary red flags in this mechanical sensory model. Malebranche saw sensations as no more than translations in the mind of mechanical impacts in the brain, occasionally caused by corpuscular motions in it and the nerves, translations and motions truly caused by God in an orderly and providentially well-designed process. And yet his distrust of the senses was foundational: describing the senses as relentlessly deceptive, he held that they serve only the body and "harness the soul to what they represent to it... the senses... do not represent things to it according to what they are in themselves but only according to their relation to the body" $(S T, 80)^{16}$. This was not simply because of his Cartesianized Augustinian belief that the Fall had given the body tyrannical power over the soul, for he also held that the senses deceived even in Eden. A design that then had been highly adaptive remained so in many ways, but had also become intensely problematic for postlapsarian people ${ }^{17}$. As a philosopher, Malebranche's own experience of the environment in which the fallen had to function was Paris from the 1660s until 1715. Exploring the ramifications of his science of motionbased sensation for his fashionable contemporaries helps illuminate his epistemological distrust of sensation and the magnitude of his challenge to their worldly quality of taste. 


\section{Inconstancy, Thy Name is Taste}

7 A key focus for Malebranche in considering sensation was pain and pleasure, which he thought of as mental qualities designed to demarcate the most important and useful messages the body sends the mind about its needs. For him it was foundational that every human mind is innately inclined to pleasure: "all men like pleasure, they all like pleasant sensations, and in this they all have the same inclination" $(S T, 64)^{18}$. Highly adaptive for survival and well-being, pleasure draws us to everything good for our bodies ${ }^{19}$.

Malebranche believed that a pleasant sensation for one person was pleasant for all who felt it (65), and that all humans were wired to respond similarly to and feel the same degree of pleasure from the same sensations (64). Such assumptions seem, at first, to make it difficult to explain taste variations. How, then, account for taste, that is, people's instinctive likings, disgusts, and related judgments about aesthetic and pleasing qualities? For all observers, including Malebranche, it was vexingly obvious that tastes varied wildly and that people were not taking pleasure in the same things. Although not a worldly theorist of taste, Malebranche was thus led to consider it at length in treating sensation. His conclusion was that different tastes prove that our sensations of the same objects vary and therefore that the senses only provide a relational truth. This meant that taste, too, was only relational, and that it could not be aligned with reason.

"All men", he said, "like pleasant sensations, [...] Hence they do not all receive the same sensations from the same objects, since they do not like them equally. [...] It is certain, then, that a sensation that is enjoyable to one person is enjoyable to everyone who feels it, but on account of the different disposition of the sense organs, the same objects do not produce the sensation for everyone." ${ }^{20}$ (64-65) If pleasurable sensations, such as sweetness, do please all who sense them, then we can only explain differences in individuals' pleasure from sweets as due to their not deriving the same sweet sensations from them: "Thus, when a man says, I like what is bitter and cannot stand sweets, it can only mean that he does not have the same sensations as those who claim to like sweets, and who dislike what is bitter." ${ }^{21}$ (65) Such a person fails to sense the sweetness of honey, and should say instead that he doesn't like honey, not that he doesn't like sweetness (64-65). Malebranche refused to believe that some people really do like bitter flavors over sweet ones, that they take pleasure from different sensations. It had to be, he thought, that organic variability makes some taste what is sweet as something else. He never even began to imagine that some might like pain, in some settings, insisting that while people are more or less sensitive to pain, no one likes it, for we all "like pleasure, ... pleasant sensations" (64). This foundational belief that every human mind will enjoy or dislike the same sensation in the same way would seem to make Malebranche the perfect philosopher of a standard of good taste as le monde understood it. But developing a physio-psychology that supported that hierarchical outlook would have to await the worldly theorists who re-appropriated his thought to those ends in the eighteenth century. For Malebranche, the discussion of taste was only meant to show the pure relativity of the senses.

10 What science lies behind these claims about taste preferences as due to sensory difference? On some level, Malebranche was continuing the venerable Galenic medical tradition that held that varying balances of the four humors create diverse constitutions, and that our irreconcilably different tastes for food and drink, which tell our organic 
needs, should be respected and catered to (which is why aristocrats who made claims about standards of le bon goût would have their cooks prepare multiple dishes for dinner parties, following the dictum that on ne doit pas disputer des gouts when it came to the table $)^{22}$. But he reframed preference and pleasure through a mechanics of sensation, imagining animal spirits moving in nerves and brain fibers. In this model, taste variations were caused by different consistencies of brain tissue, fluctuating animal spirits, and altering balances between both. At base, this was about varying forces and strengths of mechanical impressions on the brain, variations which were then coded as pleasurable or painful in the mind (ST, 50-51).

11 Malebranche held that each person's sensory physiology is unique and in constant flux. Numerous shifting mental and physical factors - internal processes and environmental inputs - influence the sense organs, animal spirits, and cerebral and nervous fibers. All these factors change the balance between the spirits and the brain tissue, causing sensory, cognitive, and emotional effects such as taste differences between individuals, and fluctuating tastes over time. Thus, Malebranche reduced "nearly all the great diversity observed among minds" to differences in balance between "the pressure of the animal spirits" and the more or less yielding brain tissue $(S T, 89)^{23}$. He thereby refigured pain and pleasure, mental acuity, rationality, emotional temperament, taste, and susceptibility to sensory impressions, the passions, and the thoughts of the imagination, casting them all in terms of a mechanical interplay between spirits and fibers measured by pressure, resilience, softness or toughness, and so on.

Take, for example, ingestion: different kinds and amounts of food and drink, Malebranche thought, affect the body through the makeup and quantity of the chyle, creating different kinds and amounts of spirits in the stomach, blood, heart and brain, changing their quantity, speed and energy levels $(S T, 91-93)^{24}$. If strengthened, the spirits produce deeper traces in the brain, and thus stronger cognitive and emotional effects in the mind; however, these effects vary because each person's brain tissue is constituted differently. Given the right constitution, a stronger flow of spirits might result in a strong mind, capable of attention and analysis; but in a soft brain, it might lead to a heightened and fickle interest in matters of taste, causing mental superficiality (130-131). In very susceptible brain fibers, even weak spirit flows might lead to deluded and visionary imaginations, though not utter madness, which is caused by "an involuntary and disordered impression of the animal spirits"25 (162-163).

If we pursue Malebranche's treatment of ingestion and health more generally, we encounter at least two ways that sensation and our predilections change because of fluxes in spirit flows. First, we receive changing sensations from the same objects, as with a wine we usually like, but find unpleasant if ill $(S T, 64)$. Our altered spirits due to, say, fever, must, concluded Malebranche, have changed our sensations of the wine, for "if the sensation remains the same, it must always be pleasant" ${ }^{26}(65)$. Further, our fluctuating spirits due to health or ingestion might affect us more broadly, physically and mentally, perhaps making us sleepy and muddle-headed, perhaps sharpening our wits, any of which would alter our sensory perceptions ${ }^{27}$. Without even bringing the nervous and cerebral fibers into the equation, Malebranche could invoke changes in the spirits caused by ingestion and health to account for any number of mental phenomena, including fluctuating and idiosyncratic sensory receptions of our own bodily state and of our sensations of external objects. 
course, health and ingestion were only two factors affecting the spirits in Malebranche's account: he further claimed that they were affected by air quality, our state of wakefulness, and our passions, inclinations, imaginings, and other kinds of thoughts $^{28}$. Leaving the spirits aside, brain tissue differed by age, sex, environmental exposure, or even just natural inflexibility or some other constitutional problem ${ }^{29}$. Altogether, he held that there were infinite permutations and combinations of shifting spirits and fibers. This of course meant infinite taste differences ${ }^{30}$.

Here we have a sensory model that explains why human beings react differently from each other to the same stimulus, why the same individual reacts differently over time to the same thing, and why different stimuli elicit identical sensations in different people. Our ever-changing physiologies, reflected in our changing sensations, are, here, a function of our baseline constitution and its internal variations, as well as the varying conditions, needs and desires of our bodies within shifting external environments. How the body's changing needs and contexts become known to us is through those fluctuating sensations, which generally guide us through some sort of pleasurable or painful component, because these qualities can most directly seize our attention. Malebranche was full of admiration for the brilliance and flexibility of a Providential neurological design that released mankind from the need to give considered rational attention to immediate physical survival or well-being in constantly altering environments. God had designed man, he thought, so that our rational minds could concentrate on intellectual truths, while our bodies would unconsciously fend for themselves via sensation ${ }^{31}$. Unfortunately, however, after the Fall our bodies' sensory messages had come to overwhelm our minds, occupying them with the trivial bodily matters which sensory automaticity was designed to avoid, and so drowning out thought ${ }^{32}$.

\section{Motions in the Brain, Taste Reactions in the Mind}

16 To delve more deeply into Malebranche's taste mechanics, let us recall that impactcaused corpuscular motion, first, externally, and then via spirits in nerves tracing their way through brains, causes sensation in the mind. While brain motion is only the occasional cause of mental feeling, the same sensation in the mind consistently follows the same motion in the brain, with other sensations regularly attached to other motions ${ }^{33}$. Given that particular individuals don't experience the same feelings about the same objects, those objects must not be producing the same motions in their brains. Those motions, then, are what drives our tastes.

17 But why would the same object not produce the same motion in individual brains? This, Malebranche explained, was because the human sensory apparatus, brain included, varies in how it receives the physical impacts of objects, in how the spirits and fibers absorb and transmit impact and motion:

Though the same motion of fibers terminating in the brain may be accompanied by the same sensations in all men, if the same objects happen not to produce the same motion in their brain, they consequently will not excite the same sensations in their soul. Now it seems to me beyond question that everyone's sense organs, not being disposed in the same way, cannot receive the same impressions from the same objects. ${ }^{34}(64)$

Going back to sweetness, Malebranche would say that we do all like it, but we don't all experience the brain motions linked with the mind's sensation of sweetness from the 
same foods and drinks. Likewise, people see colors differently because the same external objects impact their differently-constituted sense organs, nerves and brains to different mechanical effect, or because of the changing constitution of their spirits, or because of some combination of these things, all of which affect the resulting motions in the brain. Our "organs of sight as well as of hearing and taste" all differ; "there is no reason to suppose a perfect resemblance in the optic nerve of all men" (66) ${ }^{35}$. Men, women, and children thus experience "quite different motion and consequently quite different sensations" from "the same blow" (64) ${ }^{36}$. In short, the variations in how our bodies mechanically absorb physical impacts - influenced by multiple factors - account for the fact that the same objects produce different motions in different brains. And to those different motions are linked our different and changing sensations, reactions, pleasures, pains and tastes ${ }^{37}$.

With so many factors mechanically affecting how our sense organs respond to stimuli, it's remarkable that we ever agree on any of our sensations. Even when we appear to, we wouldn't know if we were only agreeing at the level of language, one man's blue being another's green (66). Malebranche thought, in fact, that any accord might actually be impossible: "Since there are no two people who can be guaranteed to have identical sense organs, it cannot be guaranteed that there are two people in this world having completely the same sensations of the same objects." ${ }^{38}(64)$ No wonder people argue about taste; $d u$ gustibus non disputandam est, indeed.

But did Malebranche mean this sensory model to apply to aesthetic taste? ${ }^{39}$ Its honnête supporters in the period would surely object, for accepting such mechanical, relativistic views would debase their exalted faculty of mind and undermine their notion of good taste, one affirmed by the contemporary dictionaries which invoked worldly authorities in their examples of usage. For those in le monde, this interpretation of the delicate pleasures taken in paintings and tragedies, or the mysterious predilections and reactions that identify those of good and bad taste, would be troubling.

21 Malebranche indeed insisted on the point: for him, what we feel, sense and perceive are only the counterparts of brain motions. Extrapolating, this means that whether we are reading Homer or the Princesse de Clèves, or being beaten, we are receiving in our bodies, and experiencing in our minds, the sensory effects of mechanical input. The nerves transmit motions to the brain in the same way, however they are struck. Whether through the visual impact of print on eyes, the audible impression of sound on ear drums, particles striking tongues and olfactory nerves or the mechanical force of stick on flesh, nerves vibrate or animal spirits move within them, leading to moving spirits and brain fibers. We remain familiar with the longstanding use of mechanistic metaphor in our language of emotion and aesthetic feeling; Malebranche, however, meant such things literally, because he was engaged in a scientific quest to understand mental reactions within bodies, according to the mechanical laws governing matter. For him, motion in body and brain caused (occasionally) sensation and emotion, including taste, in the mind. He would deny any categorical distinction between the sensations received from hearing an opera, reading a book, or eating a fine ragoût. Taste, qua sensation, could not be differentiated from any other physically-caused sensation in this mechanical model, which eschewed scholastic occult qualities and causality in understanding the matter that makes up the human body, including its brain. All this was to be understood in terms of mechanics: motion in matter underlay every thought, feeling and judgment. Malebranche 
thus made it clear that "taste" fit in the basic category of physical sensation, and that there was no distinction between physical and aesthetic pain and pleasure:

Some like music a great deal and others are indifferent to it. Even among those who enjoy it, some like one kind of music, others another, depending on the almost infinite variety found in the aural fibers, the blood, and the spirits. How much difference there is, for example, between the music of France and that of Italy and of China and of other lands, and as a result, between the taste these different peoples have for the different kinds of music. It even happens that one receives different impressions at different times from the same concerts. If your imagination is carried away by a great abundance of agitated spirits, you enjoy listening more to robust music that allows more dissonances than to more mellow music, which follows rules and mathematical precision more closely. ${ }^{40}(64)$

Malebranche did not use the anecdote of how people respond differently to being hit as an analogy for aesthetic reception, but used the experience of physical violence on the surface of the body to illustrate what was happening in the broader category of sense reception ${ }^{41}$. Sounds, like blows, created "impressions" on the brain, and "taste" was just an experience of physical impact. This, of course, flew in the face of worldly ideologies that valorized the aesthetic and the pleasurable; it demystified human tastes, for now there was nothing elevated or even meaningful about enjoyment of music or about musical tastes, whether individual or national. Instead, taste was simply a phenomenon that proved that people experience different sensations of the same objects, and those had to be caused by organic variability in sensory reception. Musical appreciation was only an involuntary, uncontrollable physical reaction of shifting spirits and different kinds of fibers in the face of aural bombardment, along with what one had eaten, how hot it was, what air one breathed, what musical sensations one was used to, and how one's passions and imagination were just then faring. All resulted in a constantly fluctuating interplay between the spirits and cerebral and nervous fibers, which meant different motions and amounts of pressure that the spirits cut into the brain.

This same relativistic and idiosyncratic sensory receptive process applied to art, literature, fashion, language, manners and all the areas le monde considered as having to do with taste preferences and judgments, as to any other physical thing perceived through the senses, for this was a Cartesian universe that contained only mind and the different forms of matter affecting it. There was no categorical difference between the ragout and the opera, for outside of res cogitans there was only res extensa, governed by universal laws of motion. Malebranche did take into account cultural habituation, the passions, and the imagination, as factors affecting taste, but he still effectively materialized the resulting taste experience by making taste sensations in the mind the immediate consequence of occasional causes (motions) in the body: cultural factors and emotions affected the spirits and fibers, and only in that way did they affect taste ${ }^{42}$.

"This matter", Malebranche went on, "is of utmost importance for both physics and morals"43 (65). Indeed, what clearer proof could exist of how bodies affected minds and promoted error? Everything we think we know of the world through sensation was baseless, for differing so in their reports, the senses could not be accurately reporting its true nature. In the Cartesian view, the senses gave people a truth that was relative to their own bodies' needs, about which they had been designed to provide adaptive, "realtime" reports. Such sensory relativism was functional and flexible, and explained why, in spite of people being wired to respond similarly to the same sensations, those same sensations weren't consistently elicited by the same things. The problem lay with 
individuals drawing erroneous conclusions from their sensations, about the nature of external reality - thinking the wine really was bitter or sweet. The wine might be neither, for the senses tell trapped, embodied minds always and only what their bodies need. Sensory judgments are not meant to speak of our true goods, reason, or the nature of external reality. But people do not understand that they are constantly misreading the world, that what they sense is not real ${ }^{44}$.

\section{Fictions of the Cultivated, Pleasing Self} standards of taste, for it implied that the tastes in which le monde placed such stock did not reflect real human goods, reason, mental refinement, or even the real world. Those tastes, as Malebranche argued, were only idiosyncratic epiphenomena reflecting bodily needs, inappropriately pushed by the body into mental awareness. Tremendous confusion between tastes and judgments of reality and of worth resulted. Moreover, Malebranche insisted that bodies were always changing and that their disparities determined sensory reactions, thus constantly altering tastes and aesthetic rulings. With as many tastes as bodies, themselves differing from one moment to the next, the worldly notions of a mysterious good taste whose judgments were always automatically in line with reason, and of a standard of taste, were nullified ${ }^{45}$. And as for the emerging aesthetic realm so dear to the French elites, Malebranche's motion-based science of sensation made all our sensations equally "aesthetic", but only if one meant by that term, that which is sensed and experienced through bodily motions; there was no place for a sublimated "aesthetic" realm of instinctively regulated judgment about beauty and the pleasing in minds constantly swayed (literally and figuratively) by motions ${ }^{46}$.

Further, with tastes reduced to brain motions in a way that denied them any special status or heightened spiritual qualities of discernment, there could be no place for the key honnête commonplace of a delicate, exquisitely comparative taste, formed by exposure to good works, polite society and conversation ${ }^{47}$. For Malebranche, such an "education" was only sensory stimulation, habituation, and comparison. As such, it was less mental training than a miseducation that trained the body and ruined the mind, for the last thing the mind should be encouraged to do is pay attention to the senses ${ }^{48}$. Moreover, worldly cultivation assumed a standard of taste (even when taste is premised on pleasure, not the rules) but with no attainable standard, there would be no rational point in "refining" one's experiences of art or conversation. In short, the central honnête notion of refining one's taste reactions made no sense if, as Malebranche insisted, these reactions vary with the body's state, register nothing truthful about most of the properties noticed in the various forms of matter encountered, reflect idiosyncratic bodily motions rather than real qualities of excellence in objects, and are unworthy of the mind's attention. Moreover, they are unjustifiable because they distract us from our true focus, God. Worse, Malebranche accused, in enjoying "pleasant sensations [...] you extort favors from Him [...] for with criminal skill you produce motion in your body that forces Him, as a result of the laws" of nature, to cause the experience of pleasure (ST, 359-360) ${ }^{49}$. Honnête taste cultivation misled and debased the mind, was epistemologically absurd, and was sinful. This might well give pause to the French Catholic elites.

Finally, just as honnête writers and salon-goers were declaring that the essence of social behavior and artistic and literary works was to please, Malebranche was casting doubt on 
that central mondain value, given the physical arbitrariness of what does please people. How could artists or conversationalists know how to please any individual embodied mind through affecting its brain's motions? What creation could please all people, or the best minds, or the people of good taste in all times and places, if pleasure were the register of tasteful behavior and creations, as le monde believed, when - as Malebranche maintained - pleasure was only a fluctuating epiphenomenon of brain motions? Admittedly, pleasure was experienced in the soul, but that mental experience, as Malebranche described it, only followed from fluctuating motions in that soul's brain. It would be impossible to know how to produce the same motion in infinitely changing brains; one could only attempt to understand what was happening in one's own, and that knowledge should further awareness and detachment, not enhanced refinement ${ }^{50}$. And what would be the point in doing so or even in trying to please in such matters? Our pleasures should never be more than telegraphic reports of our bodies' health and wellbeing, as unheeded by the mind as possible, for the point of knowledge through sensation was not to take up the mind's attention ${ }^{51}$. Even our conversations should seek only to appeal to reason, never to sway the passions, stimulate the imagination, or touch the senses more than is either unavoidable or necessary. Malebranche's account made the honnete goal of pleasing in society and the arts unachievable, pointless, and immoral.

\section{An Augustinian Enlightenment}

As we have seen, in reducing taste to sensations touched by pleasure or disgust, Malebranche threw any special notion of figurative taste out the window. He rendered taste irrational and relativistic by having ever-changing bodily motions determine it, denying any possible link to reason or to a standard of taste. In explaining sensory variability, Malebranche both accounted for the diversity of tastes and rejected the possibility of a standard of beauty or l'agréable that could be known through sensation. His philosophy logically called into doubt the idea of an honnête taste education and the central honnête value of giving and experiencing pleasure, while reminding his readers that the cultivation of taste was useless for those seeking to understand the true nature of the world, and had deep and dangerous moral and epistemological effects.

In all this, we can view Malebranche as a good Cartesian, methodically revealing the falseness of worldly beliefs about taste ("good" or "bad") and emptying it of significance. Le monde's beliefs about the value of taste were wrong, because taste "thinking" itself was erroneous. Indeed, I would go further and argue that the Recherche is an Enlightenment text: it set out to reveal errors and prejudices, improve epistemological method, and change common ways of thinking. But Malebranche's Cartesian epistemology and Enlightenment venture were grounded in an Augustinian understanding of an irreparably diminished human nature. Modern Cartesian substance dualism and physics were what allowed him to develop - more fully than Augustine ever could - an ancient stream of Christian negativity about the body's influence on the mind. Cartesian science illuminated Malebranche's Augustinian reality; it was the Enlightenment tool through which he could understand the postlapsarian world as it truly was. He then used every Enlightenment rhetorical tactic at his disposal to explain this world, and our place in it, for the betterment of mankind.

Malebranche launched a fundamental philosophical attack on dominant cultural practices, ideals and ways of thinking, one which I believe was also critical to the origins 
of the Enlightenment. However, the scholarly consensus about taste has been that it wasn't thought of in physiological terms in this period. Malebranche has thus been almost entirely overlooked from this angle ${ }^{52}$. Ignoring France's leading Cartesian and most controversial theologian was not, however, an option for contemporary French polite society ${ }^{53}$. I contend that, if fully heeded, Malebranche's caustic conclusions about relativistic mechanical sensory taste should have altered the sources of concern elite people might have had about their tastes, replacing likely anxieties as to whether they had good taste or how they could improve their taste (or at least appear to), with worries that their tastes were meaningless, futile, nothing in which to take pride, and dangerous distractions from true knowledge. This did not happen, however, because of the way in which his worldly readers chose to interpret him.

Malebranche could not control their reception of his thought, and so, ironically, helped establish an Enlightenment physio-psychology that privileged taste as a mental quality and sought to refine and heighten the mechanical, motion-based bodily processes underlying sensation in ways that would have horrified him. Polite people like Montesquieu, Madame de Lambert, the abbé Du Bos and their readers found his scientific explanation for the mechanics of sensation and taste compelling, but ignored the Augustinian interpretation and occasionalist causality. Without those, much of Malebranche's explanations for sensation and taste came across as neutral, "materialist" science, and became available for cooptation by worldly people to prove their natural mental and tasteful superiority. Elements of Malebranche's science came to inform much of the eighteenth-century understanding of taste and psychology more generally. They contributed to Enlightenment materialism and to a French obsession with perfecting taste and cognition through, and not in spite of, the body. Malebranche thus left a tremendous, deeply ironic, intellectual legacy for Enlightenment thinkers who concerned themselves with these matters, and for the worldly society of which he was so critical, which would host and protect the taste-fixated philosophes.

Paying attention to Malebranche, and connecting him to elite worldly concerns about taste, reminds us of how much of the Enlightenment's intellectual origins lie in religious thought, and of how le monde's conversation with philosophers like him played a part in its intellectual, social and cultural origins. Awareness of his thought and these connections is important if we want to understand the complex intellectual genealogy and historical context of Enlightenment theories of taste, psychology and human nature. A concept like taste, of great concern to the social elites, helps us bring philosophy and polite society back together into the Enlightenment, without falling back into a pure history of ideas, or assuming that every salon was a straightforward, deliberate space for the Enlightenment.

\section{NOTES}

1. «Car le bon goût se fonde toûjours sur des raisons tres-solides mais le plus souvent sans raisonner ", (Antoine Gombauld, chevalier de Méré, De la conversation, in Euvres complètes, t. 2, 
Charles-H. Boudhors ed., Paris, Les Belles Lettres, 1930, p. 128-129). All translations from the French are my own, unless otherwise indicated.

2. «Il y en a qui, par une sorte d'instinct, dont ils ignorent la cause, décident de ce qui se présente à eux, et prennent toujours le bon parti. » (La Rochefoucauld, « Réflexions diverses. Du goût ", in Réflexions ou sentences et maximes morales [1665], quoted in Raymond Naves, Le Goût de Voltaire, Paris, Librairie Garnier frères, 1938, p. 57).

3. « Le bon goût est le premier mouvement, ou pour ainsi dire, une espèce d'instinct de la droite raison, qui l'entraîne avec rapidité, et qui la conduit plus sûrement que tous les raisonnements qu'elle pourrait faire. » (Dominique Bouhours, La Manière de bien penser dans les ouvrages d'esprit. Dialogues, Amsterdam, Abraham Wolfgang, 1688, p. 376-377 [1 $1^{\text {st }}$ ed. 1687]). Bouhours' authoritative status on literary matters made him a go-to source for the new French-language dictionaries of the period. A variation of this definition, "Good taste is a natural sentiment attached to the soul: it is a type of instinct of right reason" (« Le bon goût est un sentiment naturel qui tient à l'ame: c'est une espèce d'instinct de la droite raison »), was cited by Furetière, Dictionnaire universel, $2^{\text {nd }}$ ed., 1701, s.v. « Goust, ou Goût ».

4. Bouhours is said to have been following the definition of the incredibly popular novelist and fellow traveler in the contemporary Paris literary salon scene (and hostess of the famous samedis ), Madeleine de Scudéry - "The good taste of the mind is a harmony or an accord of the mind with reason" («le bon goût en matière d'esprit est une harmonie, ou un accord de l'esprit avec la raison ») - also cited in Furetière, op. cit.

5. With the nearly always stated caveats that not all possessed the natural germ of taste which needed the right upbringing and exposure and must not be "spoiled."

6. Good general accounts of seventeenth-century worldly thought on taste are in Claude Chantalat, À la recherche du goût Classique, Paris, Klincksieck, 1992; Jean-Pierre Dens, L'Honnête homme et la critique du goût: Esthétique et société au XVII siècle, Lexington, French Forum Publishers, 1981; Michael Moriarty, Taste \& Ideology in Seventeenth-Century France, Cambridge, Cambridge University Press, 1988.

7. See, for example, Carolyn C. Lougee, Le Paradis des Femmes: Women, Salons, and Social Stratification in Seventeenth-Century France, Princeton, Princeton University Press, 1976; Pierre Bourdieu, Distinction: A Social Critique of the Judgement of Taste, trans. Richard Nice, Cambridge, Harvard University Press, 1984; Moriarty, Taste \& Ideology, op. cit.

8. Nicolas Malebranche, The Search After Truth, trans. Thomas M. Lennon and Paul J. Olscamp, Cambridge, Cambridge University Press, 1997. All references, quotations and page numbers for Malebranche, in the notes or the text, are from this edition of this work; abbreviated henceforth as ST. Original French citations are from De la recherche de la vérité in Malebranche, Euvres, vol. 1, Paris, Gallimard, coll. « Bibliothèque de la Pléiade », 1979, abbreviated henceforth as RV.

9. For example, ST, p. xxxviii, p. 80. All of Book I is a discussion of the errors of the senses.

10. For an example of one noble reader who used Malebranche to her own purposes to shore up the notions of effortless mental superiority and good taste in a feminist vein, see my article, "A Feminist Voice in the Enlightenment Salon: Madame de Lambert on Taste, Sensibility, and the Feminine Mind", Modern Intellectual History 7, n², August 2010, p. 209-238.

11. "I assume also that the anatomy of the sense organs is known, and that they are composed of tiny filaments originating in the middle of the brain" connecting it to "all our members in which there is feeling and... to the exterior portions of the body." (ST, p. 49; " Je suppose aussi qu'on sache l'anatomie des organes des sens: et qu'ils sont composés de petits filets, qui ont leur origine dans le milieu du cerveau; qu'ils se répandent dans tous nos membres où il $\mathrm{y}$ a du sentiment, et qu'ils viennent enfin aboutir, sans aucune interruption, jusqu'aux parties extérieures du corps. » $[R V$, p. 91]) The key works demarcating the seventeenth-century shift to a new research focus on the nerves were Thomas Willis's Cerebri anatome (1664) and Pathologiae Cerebri (1667). Malebranche was well aware of contemporary anatomical and physiological discoveries about 
the brain and explicitly cited the Cerebri anatome, p. 764-765. See G. S. Rousseau, "Nerves, Spirits, and Fibres: Towards Defining the Origins of Sensibility", in Studies in the Eighteenth Century III, ed. R.F. Brissenden and J.C. Eade, Toronto, University of Toronto Press, 1976, p. 137-157.

12. By "reside" he meant that the immaterial soul has a kind of awareness of what is happening in "that part of the brain to which all the sense organs lead" (ST, p. 51; " la partie du cerveau où tous les filets de nos nerfs aboutissent » [RV, p. 92]), not that it was located there or attached somehow. Malebranche doubted Descartes' placement of the soul in the pineal gland, and wasn't concerned with which part of the brain the soul was attached to, but held to the essential Cartesian tenet of the soul being joined to a part of the brain in a kind of monitoring role (ST, p. 89). He explained the Cartesian body-mind connection through occasionalism, an understanding of causality in which God causes every motion, action, thought, feeling and effect; bodies and their elements - indeed, all matter - are only occasional causes of effects, the occasions through which His power is channeled according to universal natural laws. Motions in the brain must exist for a mental event to occur - they are the specific, occasional causes of mental events - but for Malebranche, matter's occasionalist power was undermined by the fact that God's power was behind every motion and resultant feeling or thought.

13. All Cartesians assumed that matter lacked internal impulsion, needing an external force to set it in motion. Malebranche's spin on this meant that God was the true cause of all motions occasionally caused by matter.

14. «Il y a bien de l'apparence que les filets des nerfs sont creux comme de petits canaux, et exactement remplis d'esprits animaux, surtout lorsqu'on veille; et que quand l'extrémité de ces filets est ébranlée, les esprits qui y sont contenus transmettent jusqu'au cerveau les mêmes vibrations qu'ils reçoivent de dehors. » (RV, p. 91); « les secousses des filets continuées jusqu'au cerveau » (ibid.).

15. Malebranche's bottom line on the nerves was that "so long as one is awake and in good health one end cannot be moved without the other being moved at the same time, since they are always made somewhat taut by the animal spirits they contain - just as one part of a taut string cannot be moved without the other being disturbed" (ST, p. 49) ("pendant que l'on veille, et qu'on est en santé, on ne peut en remuer un bout, que l'autre ne se remue en même temps, à cause qu'ils sont toujours un peu bandés, par les esprits animaux qu'ils contiennent; de même qu'il arrive à une corde bandée, de laquelle on ne peut remuer une partie sans que l'autre soit ébranlée » $[R V$, p. 91]). Book I, chap. xx explains the workings of the sense organs. On the animal spirits, see ST, p. 91-100, RV, p. 147-158. Malebranche defined them as "the most refined and agitated parts of the blood, which is refined and agitated principally by fermentation and by the vigorous movement of the ... heart" (ST, p. 91; « les esprits animaux ne sont que les parties les plus subtiles et les plus agitées du sang, qui se subtilise et s'agite principalement par la fermentation et par le mouvement violent des muscles dont le cœur est composé » [RV, p. 147]); these parts are so tiny they can leave the bloodstream to enter the brain. On these tiny particles long conceptualized to explain life, the brain's control of the body, and the workings of the embodied soul, see C.U.M. Smith et al., The Animal Spirit Doctrine and the Origins of Neurophysiology, Oxford, Oxford University Press, 2012; and Sidney Ochs, A History of Nerve Functions: From Animal Spirits to Molecular Mechanisms, Cambridge, Cambridge University Press, 2004.

16. « Les sens appliquent donc extrêmement l'âme à ce qu'ils lui représentent. [...] [L]es sens [...] ne lui représentent point les choses selon ce qu'elles sont en elles-mêmes, mais seulement selon le rapport qu'elles ont avec son corps. » (RV, p. 133)

17. ST, p. xxxviii, p. 20-23, p.52. Alison Simmons brilliantly argues that, for Malebranche, the senses had to be deceptive in "Guarding the Body: A Cartesian Phenomenology of Perception", in Contemporary Perspectives on Early Modern Philosophy, ed. Paul Hoffman and Gideon Yaffe, Peterborough, Broadview Press, 2008, p. 81-113. 
18. «Cependant tous les hommes aiment le plaisir : ils aiment tous les sensations agréables; ils ont tous en cela la même inclination. » (RV, p. 112)

19. For example, ST, p. 21-22; and, in a later chapter, this remark: "pleasure and pain... are the natural marks of good and evil" (ST, p. 66) that we are wired to sense in relation to what can help or harm us; they do not accompany less critical sensory messages like colors («Cela se marque par le plaisir et la douleur, qui sont les caractères naturels du bien et du mal. » [RV, p. 115])

20. «Tous les hommes aiment [...] les sensations agréables [...] Ils ne reçoivent donc pas les mêmes sensations des mêmes objets, puisqu'ils ne les aiment pas également. [...] Il est donc certain, qu'une sensation qui est agréable à une personne, l'est aussi à tous ceux qui la sentent, mais que les mêmes objets ne la font pas sentir à tout le monde. » (RV, p. 112-113)

21. «Ainsi quand un homme dit : J'aime ce qui est amer, et je ne puis souffrir les douceurs; cela ne signifie autre chose, sinon qu'il n'a pas les mêmes sensations que ceux qui disent qu'ils aiment les douceurs, et qu'ils ont de l'aversion pour tout ce qui est amer.» $(R V, \mathrm{p} .113)$

22. On this and on how contemporary French dictionary definitions of taste distinguished between its literal and figurative meanings in assuming standards for aesthetic taste but not for tastes for food, see Jean-Louis Flandrin, "Distinction through Taste", in Passions of the Renaissance, ed. Roger Chartier and trans. Arthur Goldhammer, Cambridge, Belknap Press of Harvard University Press, 1989, p. 292-297.

23. «Ainsi la profondeur, et la netteté des vestiges de l'imagination dépend de la force des esprits animaux, et de la constitution des fibres du cerveau; et c'est la variété qui se trouve dans ces deux choses qui fait presque toute cette grande différence, que nous remarquons entre les esprits.» (RV, p. 146) Here, Malebranche was comparing the imagination, the soul's power of "imprinting" "images of objects [...] in the fibers of its brain" by the traces the spirits leave in brain matter, to engraving: "the depth and clarity of the traces in the imagination depend upon the pressure of the animal spirits, and upon the constitution of the brain fibers"; this interplay affected the resulting strength and clarity of mental images (ST, p. 89) («l'imagination ne consiste que dans la force qu'a l'âme de se former des images des objets, en les imprimant pour ainsi dire dans les fibres de son cerveau " [RV, p. 145]). This same interplay necessarily affected the senses too in the mechanical brain: "there is such a close relationship between the senses and the imagination that they should not be separated [in analysis] [...]. [T]he difference between these two faculties is but one of degree", (ST, p. 87; « Il y a un si grand rapport entre les sens et l'imagination, qu'on ne doit pas les séparer. [...] [C]es deux facultés ne diffèrent entre elles que du plus et du moins. » [RV, p. 142])

24. On mechanical and fermentation models of digestion, see Emma C. Spary, Eating the Enlightenment: Food and the Sciences in Paris, 1670-1760, Chicago, University of Chicago Press, 2012, esp. chap. 1.

25. «Il y a deux sortes de personnes qui ont l'imagination forte dans ce sens. Les premières reçoivent ces profondes traces par l'impression involontaire et déréglée des esprits animaux, et les autres, desquels on veut principalement parler, les reçoivent par la disposition qui se trouve dans la substance de leur cerveau. » (RV, p. 245-246)

26. «Cependant, si elle [la sensation] est toujours la même, il est nécessaire qu'elle soit toujours agréable. » (RV, p. 114)

27. ST, p. 92-93.

28. Ibid., p. 91-99. External factors were air, food; internal, "involuntary stimulation of certain nerves" (ST, p. 99; « l'agitation involontaire de certains nerfs » [RV, p. 158]) covered the rest.

29. Ibid., p. 110-111, p. 130-133, p. 155-157.

30. For example, $S T$, p. 64, p. 89.

31. Ibid., p. 21, p. 23, p. 79-80.

32. Ibid., p. xxxviii, p. 22, p. 79-80, p. 339. 
33. See n. 12. Malebranche thought God could link different sensations to the same motions in the brain, so that we might, for example, all see different colors from our similar brain motions. However, he thought it "more reasonable to believe that God always acts in the same way in establishing the union between our souls and bodies, and that He joins the same ideas and sensations to similar motion of the brain's interior fibers in different people" (ST, p. 64; «Il est bien plus raisonnable de croire, que Dieu agit toujours de la même manière, dans l'union qu'il a mise entre nos âmes et nos corps; et qu'il a attaché les mêmes idées, et les mêmes sensations aux mouvements semblables des fibres intérieures du cerveau de différentes personnes. " $[R V$, p. 111]) This is typical of Malebranche's notion of God's general will being aligned with the most systematic, simple Order of regular physical laws. He did not think that people would never have varying perceptions of, say, colors, only that these different experiences of what people call "orange" would always be due to different brain motions.

34. "Qu'il soit donc vrai, que les mêmes mouvements des fibres qui aboutissent dans le cerveau, soient accompagnés des mêmes sensations dans tous les hommes : s'il arrive que les mêmes objets ne produisent pas les mêmes mouvements dans leur cerveau, ils n'exciteront pas par conséquent les mêmes sensations dans leur âme. Or il me paraît indubitable, que les organes des sens de tous les hommes n'étant pas disposés de la même manière, ils ne peuvent pas recevoir les mêmes impressions des mêmes objets. » (RV, p. 111)

35. « En effet, on ne peut pas douter qu'il n'y ait beaucoup de diversité dans les organes de la vue de différentes personnes, aussi bien que dans ceux de l'ouie ou du goût car il n'y a aucune raison de supposer une parfaite ressemblance dans la disposition du nerf optique de tous les hommes. » (RV, p. 114)

36. «Le même coup produit des mouvements bien différents, et excite par conséquent des sensations bien différentes, dans un homme d'une constitution robuste, et dans un enfant, ou une femme de faible complexion.» (RV, p. 111)

37. See $S T$ p. 50-51 for an account of impact on the fibers of bodily surfaces being repeated in the brain.

38. «Ainsi, n'y ayant pas deux personnes au monde, de qui on puisse assurer qu'ils aient les organes des sens dans une parfaite conformité, on ne peut pas assurer, qu'il y ait deux hommes dans le monde, qui aient tout à fait les mêmes sentiments des mêmes objets. » (RV, p. 111-112)

39. As is well known, the term "aesthetics" itself wasn't coined until the mid-eighteenth century by Baumgarten; I use it loosely here for convenience, to refer to the emerging philosophical realm that in Malebranche's day was denoted by words like taste, beauty, la belle nature, the je ne sais quoi, l'agréable, etc.

40. «Il y en a qui aiment extrêmement la musique, d'autres qui y sont insensibles; et même entre ceux qui s'y plaisent, les uns aiment un genre de musique, les autres un autre, selon la diversité presque infinie qui se trouve dans les fibres du nerf de l'ouïe, dans le sang et dans les esprits. Combien, par exemple, y a-t-il de différence entre la musique de France, celle d'Italie, celle des Chinois et les autres, et par conséquent entre le goût que les différents peuples ont des différents genres de musique! Il arrive même qu'en différents temps on reçoit des impressions fort différentes par les mêmes concerts : car si l'on a l'imagination échauffée par une grande abondance d'esprits agités, on se plaît beaucoup plus à entendre une musique hardie, et où il entre beaucoup de dissonances, que dans une musique plus douce, et plus selon les règles et l'exactitude mathématique. » (RV, p. 111-112)

41. A prominent mathematician, Malebranche similarly noted that even though mathematical rules of harmony be followed in musical composition, auditors' pleasure may not necessarily follow: "not all the musical compositions in which proportions of consonance are best observed are the most pleasant,... Nature is not abstract;... Our tastes for musical airs are not always the same in all men, nor in the same men at different times; they change in the strangest ways according to the different agitations of the spirits." (ST, p. 428; "Toutes les compositions de 
musique où les proportions des consonnances sont le mieux observées, ne sont pas les plus agréables. La nature n'est point abstraite, les leviers et les roues des mécaniques ne sont pas des lignes et des cercles mathématiques : nos goûts pour les airs de musique ne sont pas toujours les mêmes dans tous les hommes, ni dans les mêmes hommes en différents temps ; ils changent selon les différentes émotions des esprits. » [RV, p. 618])

42. Malebranche was careful about how he "touched" the minds of readers via the imagination and understood the impressions of minds upon other minds (cognitions, emotions and the imagination), whether in conversation or writing, through this kind of "materialist" lens. I discuss this in my current book manuscript, "The Appetites of the Soul: Malebranche's Science of Pleasure and the Origins of the French Enlightenment."

43. «Il est de la dernière conséquence de remarquer [ce point] pour la physique et pour la morale. » (RV, p. 113)

44. For example, $S T$, p. 60, p. 79-80.

45. For Malebranche, the mind's link to the constantly changing body means a constantly changing mind, with even the pure inclinations of the mind affected. For example, "Man never remains the same for very long; everyone has sufficient inner evidence of his changeability. At one moment we judge in one way, the next in another, on the same subject. Briefly, man's life consists only in the circulation of the blood, and in another circulation of his thoughts and desires" (ST, p. 90; "L'homme ne demeure guère long-temps semblable à lui-même : tout le monde a assez de preuves intérieures de son inconstance : on juge tantôt d'une façon et tantôt d'une autre sur le même sujet : en un mot la vie de l'homme ne consiste que dans la circulation du sang, et dans une autre circulation de pensées et de désirs; et il semble qu'on ne puisse guère mieux employer son temps qu'à rechercher les causes de ces changements qui nous arrivent, et apprendre ainsi à nous connaître nous-mêmes. » (RV, p. 146-147) To give another example: "all of men's other sensations that depend on particular passions are as unstable as the fermentation of their humors" (ST, p. 416; "Mais tous les autres sentiments des hommes qui dépendent des passions particulières, sont aussi inconstants que le peut être la fermentation de leurs humeurs. » $[R V$, p. 600-601])

46. For an overview of Baumgarten's rather different understanding of aesthetics, see Paul Guyer, "18 ${ }^{\text {th }}$ Century German Aesthetics", The Stanford Encyclopedia of Philosophy (Winter 2016 Edition), Edward N. Zalta, ed., URL = https://plato.stanford.edu/archives/win2016/entries/ aesthetics-18th-german/.

47. See, for instance, Moriarty, Taste \& Ideology, on Méré and Saint-Evremond, p. 87, p. 93-94, p. 109-110.

48. ST, p. xxxviii, p. 21-22.

49. «[avec] ces sentiments agréables [...] vous [...] arrache[z] de lui des faveurs que vous ne méritez pas ; car vous produisez avec une adresse criminelle, dans votre corps, des mouvements qui l'obligent en conséquence des lois de l'union de l'âme et du corps qu'il a établies, à vous faire goûter toutes sortes de plaisirs. » (RV, p. 519-520)

50. For example, $S T$, p. 22, p. 51-52.

51. Ibid., p. 20-21.

52. For example, Chantalat, Goût classique, op. cit., p. 62 and nn. 8, 9; cf., however, Katharine J. Hamerton, "Malebranche, Taste and Sensibility: The Origins of Sensitive Taste and a Reconsideration of Cartesianism's Feminist Potential", The Journal of the History of Ideas 69, $\mathrm{n}^{\circ} 4$, October 2008, esp. p. 538-542.

53. Geneviève Rodis-Lewis, Nicolas Malebranche, Paris, Presses Universitaires de France, 1963, p. 5. 


\section{ABSTRACTS}

This article, which seeks to connect philosophy, polite culture, and the Enlightenment, shows how Malebranche's Cartesian science presented a full-frontal attack on the worldly notion of a good taste aligned with reason. It did this by arguing that the aesthetic tastes that people experience were the result of mechanically-transmitted sensations that, like all physical sensations, were inaccurate, erroneous and relativistic. The mechanics of this process is explored in detail to show how Malebranche was challenging honnete thinking. The article suggests that Malebranche's demystifying approach was at once a hallmark of the Enlightenment, and that his views would ironically come to inform much Enlightenment thought about taste in ways he would have despised.

En cherchant à mettre en rapport la philosophie, la culture mondaine et la pensée des Lumières, cet article montre comment la science cartésienne de Malebranche lança une attaque frontale contre la notion mondaine d'un bon goût aligné sur la raison. Selon l'argumentation de Malebranche, les goûts esthétiques des individus sont le fruit de sensations transmises mécaniquement lesquelles, comme toutes sensations physiques, sont inexactes, erronées et relatives. L'exploration détaillée de ce processus révèle la manière dont Malebranche met en cause les modes de pensée de l'honnête homme. Comme le suggère l'article, l'approche démystificatrice de Malebranche devint immédiatement un trait distinctif de la pensée des Lumières, l'ironie étant que ses conceptions vinrent informer nombre de représentations éclairées du goût qu'il aurait rejetées.

INDEX

Mots-clés: Malebranche, goût, cerveau, cartésianisme, culture mondaine, Lumières Keywords: Malebranche, taste, brain, cartesianism, polite culture, Enlightenment

\section{AUTHOR}

KATHARINE J. HAMERTON

Columbia College, Chicago 